\title{
Pengaruh Pesan Kampanye No Straw Movement Di Media Sosial Terhadap Perubahan Sikap Publik
}

\author{
1 Nuri Syafrikurniasari, 2Safira Putri Widiani \\ 1\&2 Jurusan Hubungan Masyarakat LSPR Communication and Business Institute \\ Jl. K.H. Mas Mansyur, Kav. 35, Jakarta Pusat, 10220 \\ email : 1nsyafrikurniasari@gmail.com,2safira.widiani@gmail.com
}

ARTICLE INFO
ABSTRACT
The purpose of this research was to analyze the effect of the \#NoStrawMovement
message campaign conducted by KFC Indonesia on changes in community
attitudes. This research used quantitative research methods by using a
questionnaire for 100 Instagram followers @ KFCIndonesia. The sampling
technique used is nonprobability sample with purposive sampling. The theory used
was the theory of attitude change, namely the Reinforcement theory introduced by
Hovland, Janis, and Kelly (1967). The data analysis technique used is the Likert
scale, linear regression, and t-test and the results data were processed using the
SPSS program. The results showed the \#NoStrawMovement campaign message
had an influence on changes in people's attitudes, seen from the influence of the
variable X (campaign message) on variable Y (attitude change) of 0,318, meant
the variable X (campaign message) 1 unit will increase the $Y$ variable (attitude
change) by 0,318 units. In addition, the coefficient of determination (R2) is $0,462$.
This proves that the variation of variable Y (attitude change) can be explained
with variable X (campaign message) of $46,2 \%$ while the other $53.8 \%$ are explained
by other factors not included in this study.

\section{PENDAHULUAN}

Masyarakat dunia tentu akrab dengan penggunaan plastik di setiap aspek kehidupan. Desain plastik yang ringan dan tahan lama menjadi salah satu alasan mengapa kebiasaan menggunakan plastik sulit dihilangkan. Masyarakat sudah ketergantungan terhadap penggunaan plastik yang praktis tersedia di mana - mana. Tapi, hal - hal positif ini hanya dapat dirasakan oleh manusia. Plastik memiliki kandungan kimia yang berbahaya dan berdampak untuk kerusakan lingkungan. Selain itu, plastik juga sulit untuk diurai oleh bumi.

Banyak upaya yang dilakukan untuk menghindarkan kerusakan lingkungan yang disebabkan oleh plastik. Konsumsi plastik tercatat terus meningkat tiap tahunnya. Hal itu dikarenakan bahan material plastik yang tahan lama dan dapat mempermudah masyarakat di segala aspek kehidupan. Tapi, bahan plastik yang tidak ramah lingkungan serta manajemen plastik yang tidak baik, maka limbah plastik akan selalu menjadi masalah lingkungan (Tondang,2018).

Sementara itu, menurut Direktur Jenderal Pengelolaan Sampah, Limbah dan Bahan Berbahaya Beracun (PSLB3) KLHK, Rosa Vivien Ratnawati (dalam Sucahyo, 2018) timbunan limbah sampah plastik di Indonesia, diperkirakan mencapai 24.500 ton per hari atau setara dengan 8,96 juta ton per tahun. Berdasarkan data yang dijabarkan oleh KLHK, sekitar 9,8 miliar lembar kantong plastik digunakan masyarakat Indonesia per tahun. Hampir 95 persen dari data tersebut menjadi sampah (Sucahyo, 2018).

Sebagai ibu kota, Jakarta merupakan provinsi dengan jumlah penduduk tertinggi di Indonesia. Sebenarnya sebagian besar sampah DKI Jakarta dilimpahkan di tempat pembuangan akhir (TPA) di Bantang Gebang. Dalam 10 tahun mendatang, Bantar Gebang diperkirakan akan penuh dan tidak dapat menampung tumpukan sampah baru lagi. Namun selain itu, ada sampah seluas tujuh lapangan sepak bola yang dibuang ke Sungai Ciliwung setiap harinya. Sampah sebanyak itu tidak hanya dihasilkan oleh 
penduduk pinggiran kali Ciliwung. Kemudian, sampah ini akan berujung ke laut. Ini hanya yang baru terjadi di Sungai Ciliwung. Masih banyak sungai - sungai panjang di Indonesia (dalam "Darurat Sampah di Laut Indonesia", 2018).

Hal tersebut, didukung oleh pernyataan Dosen Ilmu Kelautan, Universitas Brawijaya Malang, Dr. Defri Yona (dalam Sucahyo, 2018), mengenai bahaya sampah plastik yang masuk ke laut. Seiring berjalannya waktu, lembaran sampah plastik akan terurai dalam ukuran hingga kurang dari lima milimeter. Bentuk ini disebut sebagai mikro plastik, dan memiliki tingkat bahaya yang berlipat ganda. Jika sudah berubah menjadi mikroplastik diperairan, tidak ada lagi yang bisa dilakukan sebagai penanggulangan. Akan terdapat ratusan partikel mikro plastik di dalam satu liter air laut. Faktanya, mikro plastik tidak hanya membunuh biota laut. Nantinya hal ini akan berdampak untuk manusia. Siklusnya dimulai dari ikan - ikan atau hewan laut yang menelan mikro plastik dan menyerap racunnya, lalu dikonsumsi oleh manusia.

Bentuk lain dari sampah plastik yaitu sedotan plastik yang selama ini dengan mudahnya dipakai dan dibuang. Mayoritas restoran menyajikan sedotan plastik bersama minuman. Terlahirlah konsep bahwa gelas dan sedotan saling melengkapi. Hal ini membuat orang - orang enggan mengonsumsi secara langsung dari gelasnya dan memilih menggunakan sedotan.

Di dalam data Eco Watch (dalam Hasan, 2017), hanya lima persen dari produksi plastik yang dapat didaur ulang. Sisanya dibuang sembarangan. Hal ini, disebabkan buang sampah sembarangan yang masih menjadi dari bagian budaya, sampah sedotan plastik pun berserakan begitu saja di darat dan lautan. Bersama - sama kantong plastik, manusia mengonsumsi hingga 500 miliar lembar plastik per tahun atau setara dengan 1 juta per menitnya. Oleh sebab itu, plastik bekas menyumbang $60-80$ persen dari total sampah laut. Sedotan plastik pun termasuk ke dalam 10 besar sampah yang mencemari lautan. Bahkan, dari total luas laut bumi, terdapat 46.000 limbah plastik per satu mil persegi.

Tentunya polusi ini berdampak untuk kehidupan satwa laut. Faktanya, 44 persen spesies burung laut, 22 persen mamalia laut, semua spesies penyu, dan beberapa spesies ikan terdokumentasi memiliki sampah plastik di tubuhnya, baik tertelan maupun menempel permanen di tubuhnya. Lebih kejam lagi, sampah plastik membunuh setidaknya 1 juta burung laut, dan 100.000 mamalia laut dan penyu tiap tahun (Hasan, 2017). Banyak berita beredar di internet gambar biota laiut yang terkena dampak dari limbah plastik. Mulai dari penyu yang pertumbuhan cangkangnya tidak sempurna karena terjerat plastik, ikan - ikan yang tersangkut plastik di tubuhnya, hingga seekor penyu yang diselamatkan karena hidungnya tertancap sedotan plastik.

Tetapi seiring berjalannya waktu, beberapa organisasi mulai peduli terhadap kerusakan yang disebabkan oleh limbah sedotan plastik ini. KFC Indonesia yang mencanangkan program \#NoStrawMovement bertepatan dengan perayaan Hari Terumbu Karang Internasional pada 8 Mei 2017. Bentuk nyatanya adalah dengan tidak menggunakan sedotan plastik saat memesan minuman di restoran atau di mana pun mereka menikmati minuman. Langkah pasti yang dilakukan oleh KFC Indonesia adalah dengan tidak lagi menyediakan dispenser sedotan di setiap gerai restorannya. Selain itu, bersama dengan Divers Clean Action, organisasi penyelam muda yang peduli terhadap masalah pencemaran dan sampah laut yang mempunyai misi mengurangi sampah di perairan Indonesia, gerakan \#NoStrawMovement juga melakukan aksi membersihkan sampah di bawah laut dan pantai ("KFC Tak Lagi Sediakan Dispenser Sedotan, Kenapa?”, 2017).

KFC Indonesia tidak hanya melakukan kampanye secara nyata, tetapi juga gencar melakukan edukasi kepada pelanggannya secara online melalui instagram. KFC Indonesia mengunggah foto dan video mengenai bahaya dari sedotan plastik. Bukan hanya itu, untuk menarik audiens untuk menerima pesan yang ingin disampaikan dengan baik, KFC Indonesia menampilkan infografis dan games seputar limbah plastik. Lewat instagram KFC Indonesia memberikan berbagai informasi terkait gerakan \#NoStrawMovement. Tujuan dari penelitian ini adalah untuk mengetahui apakah terdapat pengaruh pesan kampanye \#NoStrawMovement yang dilakukan oleh KFC Indonesia terhadap perubahan sikap publik.

\section{KERANGKA TEORITIS}

\subsection{Kampanye}

Kampanye merupakan suatu kegiatan yang dapat dilakukan baik individu maupun kelompok untuk membujuk atau menciptakan dampak tertentu (Ruslan, 2013, p. 25). Menurut Siegel \& Biener (dalam Liliweri, 2011, p. 677) pada tingkat paling umum, kampanye dapat dipahami sebagai metode dan teknik yang terbaik bagi aktivitas pengiriman dan pertukarang informasi yang bertujuan untuk membujuk dan 
memobilisasi khalayak sasaran. Kampanye "politik" dapat diarahkan untuk memenuhi beberapa tujuan misalnya menciptakan dialog dan diskusi melakukan lobi dengan partai politik, lembaga legislatif, atau dengan lembaga - lembaga pemerintahan, atau juga membujuk masyarakat tentang untuk mengubah sikap dan perilaku tertentu yang mengandung risiko bagi banyak orang.

\subsection{Pesan Kampanye}

Dalam mengimplementasikan program PR, menurut Cutlip, Center, \& Broom (2009, p. 408-409), pesan yang disampaikan harus memperhatikan tujuh $\mathrm{C}$, yaitu pertama, credibility (kredibilitas), komunikasi dimulai dengan iklim rasa saling percaya. Iklim ini dibangun melalui kinerja di pihak institusi, yang merefleksikan keinginan untuk melayani stakeholder dan publik. Penerima harus percaya kepada pengirim informasi dengan menghormati kompetensi sumber informasi terhadap topik informasi.

Kedua, context (konteks), program komunikasi harus sesuai dengan kenyataan lingkungan. Media massa hanyalah suplemen untuk ucapan dan tindakan dalam kehidupan sehari - hari. Harus disediakan konteks untuk partisipasi dan umpan balik. Konteks harus menginformasikan, bukan menentang, isi pesannya. Komunikasi yang efektif membutuhkan lingkungan sosial yang mendukung, yang sebagian besar dipengaruhi media massa.

Ketiga, content (isi), pesan harus mengandung makna bagi penerimanya dan harus sesuai dengan sistem nilai penerima. Pesan harus relevan dengan situasi penerima. Pada umumnya orang memilih item informasi yang menjanjikan manfaat yang besar bagi mereka. Isi pesan menentukan audiens. Keempat, clarity (kejelasan), pesan harus diberikan dalam istilah sederhana. Kata harus bermakna sama menurut si pengirim dan penerima. Isu yang kompleks harus dupadatkan ke dalam tema, slogan, atau stereotip yang mengandung kesederhanaan dan kejelasan. Semakin jauh pesan akan dikirim, pesan itu seharusnya semakin sederhana. Organisasi harus berbicara dengan satu suara, tidak banyak suara.

Kelima, continuity (kontinuitas), komunikasi adalah proses tanpa akhir. Ia membutuhkan repetisi agar bisa masuk. Repetisi - dengan variasi - berperan untuk pembelajaran dan persuasi. Beritanya harus konsisten. Keenam, channel (saluran), saluran komunikasi yang sudah ada harus digunakan, sebaiknya saluran yang dihormati dan dipakai oleh si penerima. Menciptakan saluran baru bisa jadi sulit, membutuhkan waktu, dan mahal. Saluran yang berbeda punya efek berbeda dan efektif pada tingkat yang berbeda - beda dalam tahap proses difusi informasi. Dibutuhkan pemilihan saluran yang sesuai dengan publik sasaran. Orang mengasosiasikan nilai yang berbeda - beda pada berbagai saluran komunikasi.

Ketujuh, capability of audience (kemampuan audien), komunikasi harus mempertimbangkan kemampuan audien. Komunikasi akan efektif apabila tidak banyak membebani penerima untuk memahaminya. Kemampuan ini dipengaruhi oleh factor - factor seperti waktu yang mereka miliki, kebiasaan, kemampuan membaca, dan pengetahuan yang telah mereka punyai (p. 408-409).

\subsection{Perubahan Sikap}

Menurut Sarwono \& Meinarno (2009), sikap (attitude) adalah istilah yang mencerminkan rasa senang, tidak senang, atau perasaan biasa-biasa saja (netral) dari seseorang terhadap sesuatu. Sesuatu itu bisa benda, kejadian, situasi, orang-orang atau kelompok, kalau yang timbul terhadap sesuatu itu adalah perasaan senang, maka disebut sikap positif. Sedangkan perasaan tidak senang disebut sikap negatif.

Menurut Azwar (2007), mekanisme mental yang mengevaluasi, membentuk pandangan, mewarnai perasaan dan akan ikut menentukan kecenderungan perilaku individu terhadap manusia lainnya atau sesuatu yang sedang dihadapi oleh individu, bahkan terhadap diri individu itu sendiri disebut fenomena sikap. Fenomena sikap yang timbul tidak saja ditentukan oleh keadaan objek yang sedang dihadapi tetapi juga dengan kaitannya dengan pengalaman-pengalaman masa lalu, oleh situasi di saat sekarang, dan oleh harapan-harapan untuk masa yang akan datang. Sikap manusia, atau untuk singkatnya disebut sikap, telah didefinisikan dalam berbagai versi oleh para ahli.

Menurut Fishben \& Ajzen, (dalam Dayakisni, 2015) sikap sebagai predisposisi yang dipelajari untuk merespon secara konsisten dalam cara tertentu berkenaan dengan objek tertentu. Sherif \& Sherif menyatakan bahwa sikap menentukan konsisten dan kekhasan perilaku seseorang dalam hubungannya dengan stimulus manusia atau kejadiankejadian tertentu. Sikap merupakan suatu keadaan yang memungkinkan timbulnya suatu perbuatan atau tingkah laku. Dapat disimpulkan bahwa sikap adalah 
cerminan perasaan individu yang terjadi untuk merespon sesuatu berkenaan dengan objek atau kondisi atau sesama individu. Dalam penelitian ini akan diuji perubahan sikap yang terjadi pada individu.

\subsection{Reinforcement Theory}

Menurut Liliweri (2011, p. 172), teori ini diperkenalkan oleh Hovland, Janis, dan Kelly (1967). Menurut teori ini perubahan sikap itu merupakan hasil dari perubahan opini atau pendapat komunikan dan perubahan itu dihasilkan melalui penguatan (1) perhatian (attention) yang dapat diartikan bahwa komunikator harus mempunyai kapabilitas untuk menyusun pesan yang dapat menarik ataupun meningkatkan perhatian dari diri komunikan; (2) kelengkapan (comprehension) yang berarti bahwa komunikator harus mam[u menyusun pesan yang lengkap, rinci, dan jelas yang bertujuan untuk mempermudah komunikan dalam memahami pesan yang diterima; (3) penerimaan (acceptance) yang berarti bahwa selain pesan yang menarik, lengkap, dan jelas, komunikator juga harus mampu menyusun pesan yang dapat diterima oleh komunikan dalam artian pesan tersebut tidak berbalik menimbulkan penolakan dari komunikan (Liliweri, 2011, p. 172).

Tabel 1. Reinforcement Theory

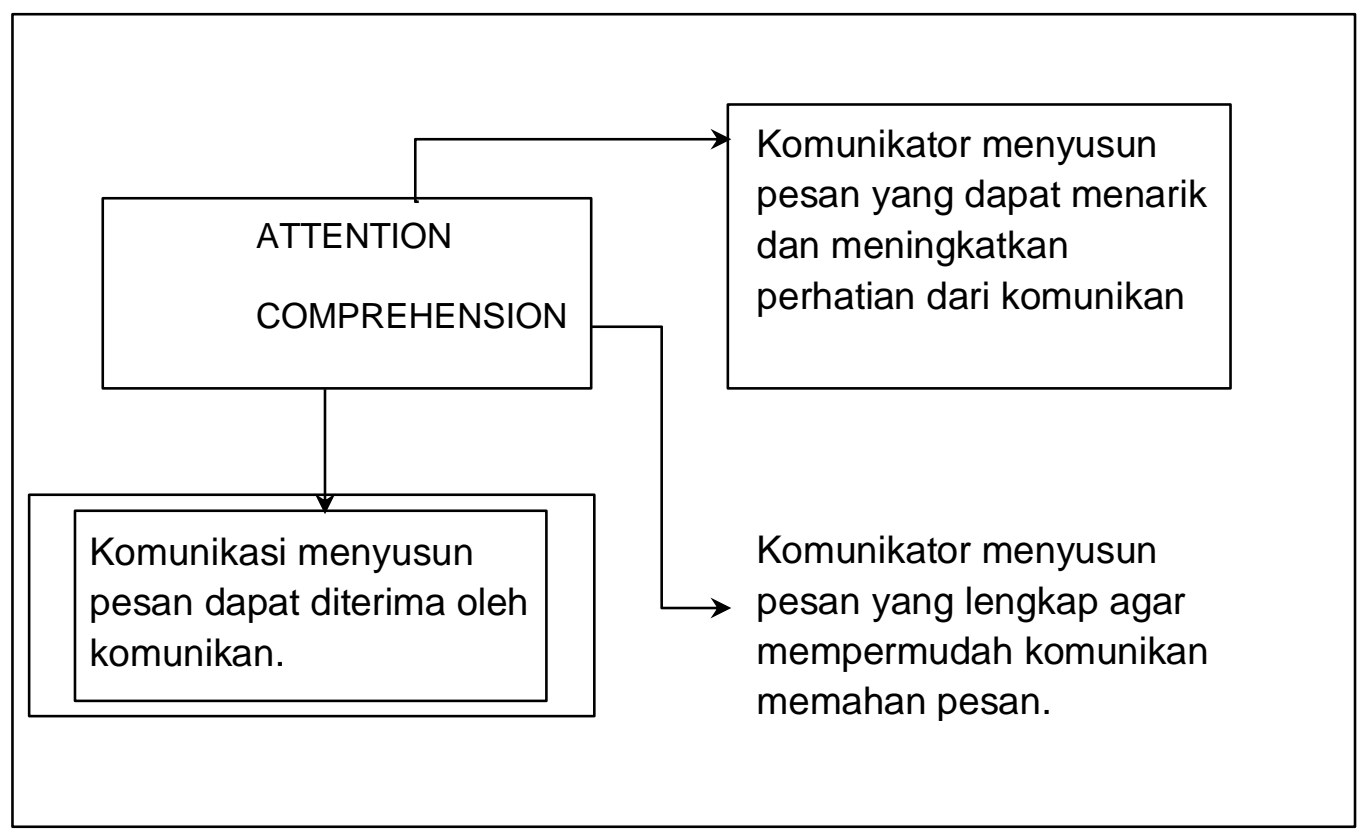

Sumber: Liliweri, 2011, p. 172.

\section{METODE PENELITIAN}

Penelitian ini menggunakan jenis penelitian kuantitatif. Judul penelitian ini adalah "Pengaruh No Straw Movement di Media Sosial Terhadap Perubahan Sikap Publik". Metode penelitian kuantitatif dapat diartikan sebagai metode penelitian yang berlandaskan pada filsafat positivisme, digunakan untuk meneliti pada populasi atau sampel tertentu, pengumpulan data menggunakan instrument peneliti, analisis data bersifat kuantitatif statistik, dengan tujuan untuk menguji hipotesis yang telah ditetapkan (Sugiyono, 2017). Oleh karena itu, metodologi kuantitatif adalah penelitian populasi dan sampel tertentu dengan suatu fenomena yang akan diteliti sehingga dapat ditarik kesimpulan dengan metode pengujian hipotesis.

Dalam penelitian ini, populasi yang diteliti adalah followers instagram dari KFC Indonesia (@KFCIndonesia). Karakteristik populasi yang akan diteliti adalah masyarakat yang mengetahui instagram KFC Indonesia dan mengetahui kampanye \#NoStrawMovement. Maka dari itu, dapat disimpulkan populasi dari penelitian ini adalah followers KFC Indonesia.

Dalam penelitian ini digunakan sampel nonprobabilitas dengan teknik purposive sampling yaitu pemilihan berdasarkan karakteristik yang dianggap mempunyai keterkaitan dengan karakteristik populasi yang telah diketahui. Kriteria yang diambil sebagai anggota sampel dalam penelitian ini yaitu followers@KFCIndonesia yang berdomisili di Jabodetabek. Rumus yang digunakan untuk mengetahui 
jumlah sampel adalah Slovin sebanyak 99,98 orang dibulatkan menjadi 100 orang. Kuesioner dibuat secara online dan akan diisi oleh 100 orang responden yang berasal dari followers akun instagram @ KFCIndonesia. Skala pengukuran yang digunakan adalah skala likert dengan rentang 1-5.

\section{Operasionalisasi Variabel X (Pesan Kampanye) (Independen)}

Tabel 2 Operasionalisasi Variabel X

\begin{tabular}{|c|c|c|c|}
\hline Variabel & Dimensi & Indikator & Skala \\
\hline \multirow{21}{*}{$\begin{array}{c}\text { Pesan } \\
\text { Kampanye } \\
(\mathrm{X}) \\
\text { (Cutlip et } \\
\text { al., 2009) }\end{array}$} & \multirow{3}{*}{ Credibility } & - Pesan yang disampaikan dapat dipercaya & \multirow{3}{*}{ Likert } \\
\hline & & - Pesan yang disampaikan dapat merefleksikan audiens & \\
\hline & & $\begin{array}{l}\text { - Pesan yang disampaikan adalah sumber yang } \\
\text { kompeten }\end{array}$ & \\
\hline & \multirow{3}{*}{ Context } & $\begin{array}{l}\text { - Pesan yang disampaikan sesuai dengan kehidupan } \\
\text { sehari - hari. }\end{array}$ & \multirow{3}{*}{ Likert } \\
\hline & & $\begin{array}{l}\text { - Pesan yang disampaikan dapat dikonfirmasi } \\
\text { kebenarannya }\end{array}$ & \\
\hline & & - Pesan yang disampaikan sesuai dengan kondisi media. & \\
\hline & \multirow{4}{*}{ Content } & $\begin{array}{l}\text { - Pesan yang disampaikan memiliki makna untuk } \\
\text { audiens }\end{array}$ & \multirow{4}{*}{ Likert } \\
\hline & & $\begin{array}{l}\text { - Pesan yang disampaikan sesuai dengan nilai - nilai } \\
\text { yang dianut audiens }\end{array}$ & \\
\hline & & - Pesan yang disampaikan sesuai dengan situasi saat ini & \\
\hline & & $\begin{array}{l}\text { - Pesan yang disampaikan memberi manfaat untuk } \\
\text { audiens }\end{array}$ & \\
\hline & \multirow{3}{*}{ Clarity } & - Pesan yang disampaikan mudah dipahami & \multirow{3}{*}{ Likert } \\
\hline & & - Pesan yang disampaikan mudah dimengerti & \\
\hline & & $\begin{array}{l}\text { - Pesan yang disampaikan menggunakan istilah - istilah } \\
\text { sederhana }\end{array}$ & \\
\hline & \multirow{3}{*}{ Continuity } & - Pesan yang disampaikan secara berulang & \multirow{3}{*}{ Liker } \\
\hline & & - Pesan yang disampaikan bervariasi & \\
\hline & & - Pesan yang disampaikan konsisten & \\
\hline & Channel & $\begin{array}{l}\text { - Pesan yang disampaikan sesuai dengan saluran yang } \\
\text { dipilih }\end{array}$ & Likert \\
\hline & \multirow{4}{*}{$\begin{array}{l}\text { Capability } \\
\text { of audience }\end{array}$} & $\begin{array}{l}\text { - Pesan yang disampaikan sesuai dengan kemampuan } \\
\text { audiens }\end{array}$ & \multirow{4}{*}{ Liker } \\
\hline & & $\begin{array}{l}\text { - Pesan yang disampaikan mudah diaplikasikan sehari - } \\
\text { hari }\end{array}$ & \\
\hline & & - Pesan yang disampaikan mudah dimengerti audiens & \\
\hline & & $\begin{array}{l}\text { - Pesan yang disampaikan sesuai dengan latar belakang } \\
\text { audiens }\end{array}$ & \\
\hline
\end{tabular}

Sumber: Data Olahan Peneliti, 2019. 


\section{Operasionalisasi Variabel Y (Perubahan Sikap) (Dependen)}

Tabel 3 Operasionalisasi Variabel Y

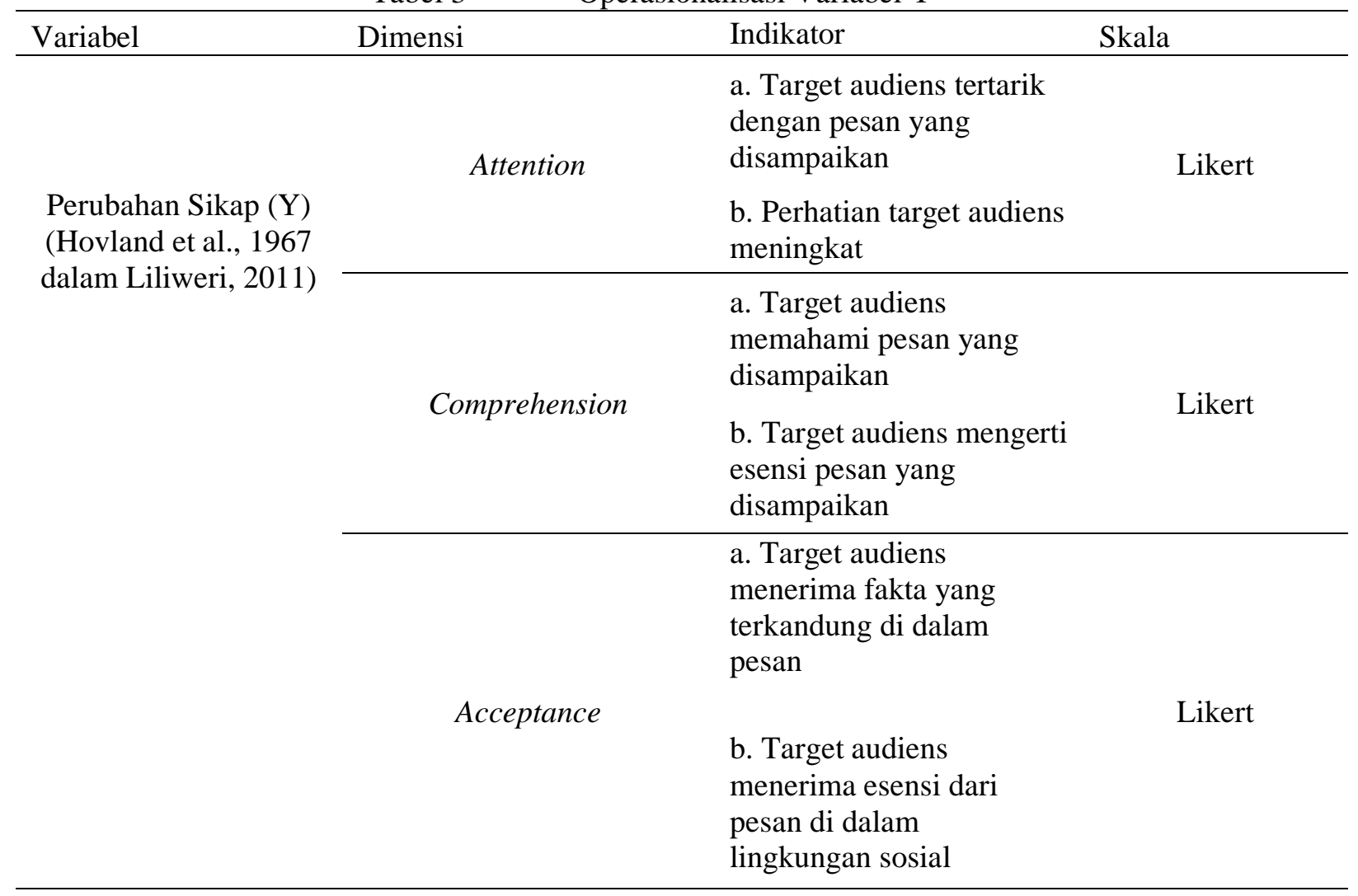

Sumber: Data Olahan Peneliti, 2019.

Dalam penelitian ini ingin menguji hipotesis hubungan antar satu variabel independen dengan satu variabel dependen. Berikut adalah hipotesis dalam penelitian ini:

Ho = Tidak ada pengaruh variabel X (Pesan Kampanye) terhadap variabel Y (Perubahan Sikap).

$\mathrm{Ha}=$ Ada pengaruh variabel X (Pesan Kampanye) terhadap variabel Y (Perubahan Sikap

\section{HASIL PENELITIAN DAN DISKUSI}

Pie Chart Karakteristik Responden Berdasarkan Usia Gambar 1 Pie Chart Karakteristik Responden Berdasarkan Usia

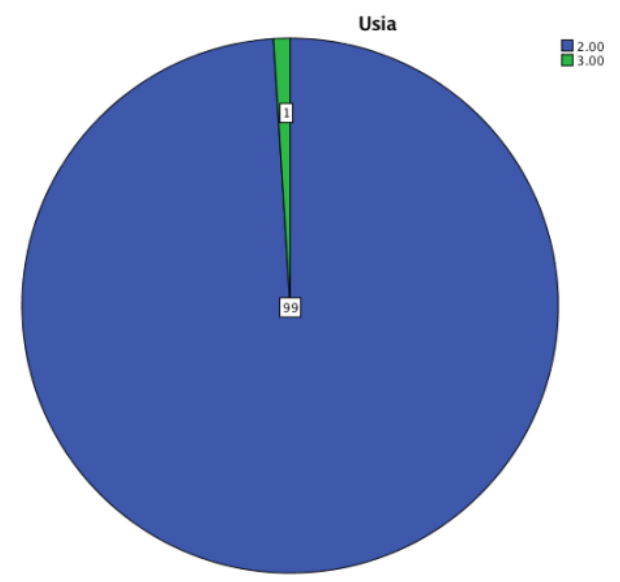

Sumber: Data Olahan Peneliti, 2019. 
Dalam penelitian ini, responden yang paling dominan berusia 20 - 24 tahun, yaitu sebesar $99 \%$ dan $1 \%$ adalah kelompok usia 25 - 30 tahun. Mayoritas responden adalah kelompok usia $20-24$ tahun membuktikan bahwa generasi milenial aktif dalam menggunakan media sosial instagram.

\section{Pie Chart Karakteristik Responden Berdasarkan Jenis Kelamin}

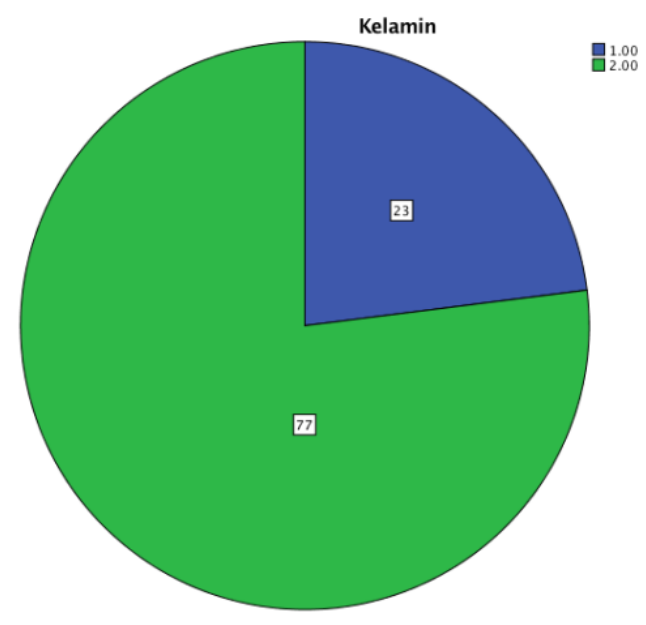

Gambar 2 Pie Chart Karakteristik Responden Berdasarkan Jenis Kelamin Sumber: Data Olahan Peneliti, 2019.

Dalam penelitian ini, mayoritas responden berjenis kelamin perempuan yaitu sebanyak $77 \%$ dan $33 \%$ sisanya berjenis kelamin laki - laki.

\section{Pie Chart Karakteristik Responden Berdasarkan Kunjungan}

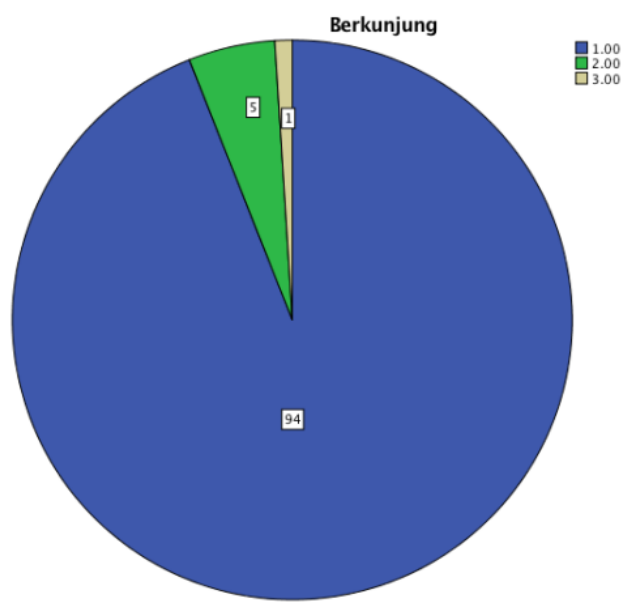

Chart Karakteristik Responden Berdasarkan Kunjungan Sumber: Data Olahan Peneliti, 2019.

Berdasarkan data olahan dalam penelitian di atas, frekuensi berkunjung responden yang paling banyak adalah seminggu sekali yaitu sebanyak $94 \%$. Sebanyak 5\% berkunjung ke gerai KFC seminggu tiga kali dan $1 \%$ sisanya berkunjung ke gerai KFC sebanyak seminggu 7 kali. Hasil penelitian menunjukan bahwa terdapat pengaruh antara variabel $X$ yakni pesan kampanye KFC Indonesia di media sosial terhadap variabel Y yakni perubahan sikap publik. Hal ini dibuktikan dengan uji t pada variabel pesan kampanye terhadap perubahan sikap. Dapat diketahui bahwa sig untuk variabel pesan kampanye adalah .000 dan jika dibandingkan dengan 0,05 terlihat bahwa sig $<0,05$ yang dapat disimpulkan bahwa Ho ditolak dan Ha diterima yang artinya variabel pesan kampanye berpengaruh secara signifikan terhadap perubahan sikap. 
Tabel 3 Coefficient

\begin{tabular}{|c|c|c|c|c|c|c|}
\hline & \multirow[t]{2}{*}{ Model } & \multicolumn{2}{|c|}{$\begin{array}{c}\text { Unstandardized } \\
\text { Coefficients }\end{array}$} & \multirow{2}{*}{$\begin{array}{c}\begin{array}{c}\text { Standardized } \\
\text { Coefficients }\end{array} \\
\text { Beta } \\
\end{array}$} & \multirow[t]{2}{*}{$\mathrm{t}$} & \multirow[t]{2}{*}{ Sig. } \\
\hline & & B & Std. Error & & & \\
\hline \multirow[t]{2}{*}{1} & Constant & 9.242 & 3.148 & & 2.936 & .004 \\
\hline & Pesan Kampanye & .318 & .035 & .679 & 9.165 & .000 \\
\hline
\end{tabular}

Sumber: Data Olahan Peneliti, 2019.

Perhitungan yang dilakukan dengan menggunakan program SPSS menunjukan hasil nilai pengaruh untuk X (pesan kampanye) sebesar 0,318 terhadap Y (perubahan sikap).

Tabel 4 Model Sumary

\begin{tabular}{ccccc}
\hline Model & $\mathrm{R}$ & $R$ Square & Adjusted $R$ Square & $\begin{array}{c}\text { Std. Error of the } \\
\text { Estimated }\end{array}$ \\
\hline 1 & .679 & .462 & .456 & 2.78929 \\
\hline
\end{tabular}

a. Predictors: Contant, Pesan Kampanye

Sumber: Data Olahan Peneliti, 2019.

Selain itu, koefisien determinasi $\left(\mathrm{R}^{2}\right)$ adalah 0,462 . Hal ini membuktikan bahwa variasi variabel $\mathrm{Y}$ (perubahan sikap) dapat dijelaskan dengan variabel $X$ (pesan kampanye) sebesar 46,2\% sedangkan $53,8 \%$ sisanya dijelaskan oleh faktor - faktor lainnya yang tidak digunakan dalam penelitian ini. Secara teori, perubahan sikap dapat disebabkan oleh peristiwa / kejadian yang dialami sendiri atau berdasarkan pemberitaan di media.

Hal tersebut, membuktikan bahwa pesan kampanye yang terdiri atas Credibility, Context, Content, Clarity, Continuity, Channel, dan Capability of audience memiliki pengaruh terhadap perubahan sikap publik yang dilihat menggunakan Reinforcement Theory yang terdiri atas Attention, Comprehension, dan Acceptance dalam penelitian ini seperti yang dilakukan oleh KFC Indonesia melalui instagram dengan \#NoStrawMovement.

Perubahan sikap menurut Azwar (2007), adalah sebuah mekanisme mental yang mengevaluasi, membentuk pandangan, mewarnai perasaan dan akan ikut menentukan kecenderungan perilaku individu terhadap manusia lainnya atau sesuatu yang sedang dihadapi oleh individu, bahkan terhadap diri individu itu sendiri disebut fenomena sikap. Fenomena sikap yang timbul tidak saja ditentukan oleh keadaan objek yang sedang dihadapi tetapi juga dengan kaitannya dengan pengalaman-pengalaman masa lalu, oleh situasi di saat sekarang, dan oleh harapan-harapan untuk masa yang akan datang. Perubahan sikap yang diinginkan adalah masyarakat menjadi sadar terhadap bahaya limbah plastik yang dalam penelitian ini berupa sedotan.

Untuk melihat sejauh mana perubahan sikap itu terjadi, diukur melalui Reinforcement Theory dengan menggunakan 3 indikator yaitu Attention, Comprehension, dan Acceptance. Untuk melakukan perubahan sikap publik terhadap kesadaran pengurangan penggunaan sedotan plastik yang tidak baik dampaknya untuk ekosistem laut, KFC Indonesia melakukan kampanye \#NoStrawMovement yang aktif dilakukan sejak 2017.

Pada tingkat paling umum, kampanye menurut Siegel \& Biener (dalam Liliweri, 2011, p. 677), dapat dipahami sebagai metode dan teknik yang terbaik bagi aktivitas pengiriman dan pertukaran informasi yang bertujuan untuk membujuk dan memobilisasi khalayak sasaran. Dalam hal ini, KFC Indonesia memberi edukasi mengenai dampak yang diakibatkan oleh limbah sedotan plastik. Edukasi yang diberikan KFC Indonesia terhadap publiknya merupakan bentuk dari persuasi. Mengingat sampah plastik di Indonesia telah mencapai titik yang mengkhawatirkan. Dimana sampah-sampah tersebut sampai mengotori laut sehingga membahayakan biota laut.

Instagram merupakan situs jejaring sosial di seluruh dunia yang menyediakan platform bagi orang untuk berbagi foto dan video dengan orang lain. Kebiasaan menggunaan smartphone dalam kehidupan sehari - hari memungkinkan Instagram untuk memperluas peran yang dimainkan oleh gambar dalam 
stimulasi, pengambilan, dan modulasi perhatian kepada publiknya. Pada Instagram dikenal istilah engagement, hal ini dapat diukur melalui jumlah likes dan komen pada suatu unggahan. Instagram saat ini tidak hanya digunakan untuk media sosial pribadi namun sudah menjadi sosial perusahaan. Pada perkembangannya media sosial oleh perusahaan tidak hanya digunakan sebagai sarana promosi namun seperti dilakukan oleh KFC instagram mereka gunakan sebagai sarana edukasi dalam kampanye sosial mereka.

Kampanye melalui media sosial, Instagram, adalah contoh dari kegiatan Online PR. Menurut Philips dan Young, salah satu alasan praktisi Public Relations memasuki dunia online adalah karena Public Relations sangat bergantung pada komunikasi kepada publiknya sehingga harus selalu mengikuti selera publik yang sekarang ini menjadi gaya hidup banyak orang. Selera yang dimaksud dalam penelitian ini adalah tren mengenai \#NoStrawMovement yang disebabkan oleh gaya hidup masyarakat belakangan ini semakin gencar dengan kepedulian terhadap lingkungan.

Hakekatnya, tujuan kegiatan Public Relations adalah terjaga dan terbentuknya kognisi, afeksi, dan perilaku positif publik terhadap organisasi atau lembaga. Namun, tujuan humas hendaknya dipandang sebagai tujuan yang netral atau bersifat dorongan antara tujuan organisasi dan tujuan publik (Dayanti et., 2015). Dalam hal ini, kampanye \#NoStrawMovement merupakan dorongan untuk kepentingan publik, yaitu lingkungan laut Indonesia agar tidak tercemar limbah plastik khususnya sedotan plastik.

Oleh karena itu, pesan kampanye komunikasi persuasi yang dilakukan KFC Indonesia di media sosial instagram dengan \#NoStrawMovement terbukti berpengaruh secara signifikan terhadap perubahan sikap publiknya.

\section{SIMPULAN}

Pesan kampanye \#NoStrawMovement yang disampaikan melalui media Instagram @ KFCIndonesia memiliki pengaruh yang signifikan terhadap perubahan sikap followers Instagram @ KFCIndonesia. Akan tetapi diperlukan pengembangkan lebih lanjut kampanye \#NoStrawMovement dengan memberi edukasi mengenai alternatif pengganti sedotan plastik. Selain itu, KFC Indonesia diharapkan mengembangkan kampanye ini menjadi \#NoPlasticMovement untuk mengurangi limbah plastik secara menyeluruh dan lebih menekankan pesan yang tertuju pada kepedulian lingkungan akan bahaya limbah plastik dengan menyelenggarakan acara yang melibatkan khalayak.

\section{DAFTAR PUSTAKA}

[1] Azwar, S. (2007). Sikap Manusia Teori Dan Pengukurannya. Yogyakarta: Pustaka Pelajar.

[2] Cutlip, S. M., Center, A. H. \& Broom, G. M. (2009). Effective Public Relations, Ed. 9. Jakarta: Kencana.

[3] Darurat Sampah di Laut Indonesia. (2018, Maret 19). Diperoleh pada 25 Oktober 2018, dari Viva: https://www.viva.co.id/gaya-hidup/inspirasi-unik/1018001-darurat-sampah-dilaut-indonesia

[4] Dayakisni, T. \& Hudainah. (2015). Psikologi Sosial. Malang: UMM Press.

[5] Hasan, A. M. (2017, April 12). Sejarah Sedotan Plastik dan Bahaya yang Diremehkan. Diperoleh pada 26 Oktober 2018, dari Tirto: https://tirto.id/sejarah-sedotan-plastik-danbahaya-yang-diremehkan-cmw

[6] KFC Tak Lagi Sediakan Dispenser Sedotan, Kenapa?. (2017, Mei 09). Diperoleh pada 26 Oktober 2018, dari Viva: https://www.viva.co.id/gaya-hidup/inspirasi-unik/913598-kfctak-lagi-sediakan-dispenser-sedotan-kenapa

[7] Liliweri, A. (2011). Komunikasi Serba Ada Serba Makna. Jakarta: Kencana.

[8] Ruslan, R. (2017). Manajemen Public Relations \& Media Komunikasi. Jakarta: Rajagrafindo Persada.

[9] Ruslan, R. (2013). Kiat dan Strategi Kampanye Public Relations. Jakarta, Indonesia: PT RajaGrafindo Persada.

[10] Sarwono, S. W., \& Meinarno, E. A. (2009). Psikologi Sosial. Jakarta: Salemba Humanika. 
[11] Sucahyo, N. (2018, Juni 08). Ancaman Plastik di Laut Indonesia. Diperoleh pada 25 Oktober 2018, dari Voa Indonesia: https://www.voaindonesia.com/a/ancaman-sampahplastik-di-laut-indonesia/4430037.html

[12] Sugiyono. (2017). Metode Penelitian: Pendekatan Kuantitatif, Kualitatif, dan R\&D. Bandung: Alfabeta.

[13] Tondang, Y. (2018, Juni 05). Sampai kapan mau membuang sampah plastik sembarangan? Diperoleh pada 25 Oktober 2018, dari Rappler: https://www.rappler.com/indonesia/berita/204172-sampai-kapan-membuang sampahplastik-sembarangan 